\title{
The role of arts activities in developing resilience and mental well-being in children and young people a rapid review of the literature.
}

Leyre Zarobe \& Hilary Bungay

\begin{abstract}
Aims: This rapid review explores the role of arts activities in promoting the mental wellbeing and resilience of children and young people aged between 11 and 18 years.

Methods: A systematic search of the literature was undertaken across eighteen databases, no date limit was set on publication. Search terms included a range of creative activities: music, dance, singing, drama and visual arts, these were combined with terms linked to aspects of mental health, emotional wellbeing, and resilience. Only studies related to activities that took place within community settings and those related to extracurricular activities based within schools were included.
\end{abstract}

Results: Following application of inclusion and exclusion criteria, 8 papers were included in the review. The interventions used in the studies were diverse and 
the research was heterogeneous, therefore a narrative synthesis of the results was undertaken. The findings from the studies are considered in terms of the contribution the activities make to building resilience of children and young people. It was found that participating in arts activities can have a positive effect on, self-confidence, self-esteem, relationship building and a sense of belonging, qualities which have been associated with resilience and mental wellbeing.

Conclusions: Although the research evidence is limited there is some support for providing structured group arts activities to help build resilience and contribute to positive mental wellbeing of children and young people.

\section{Introduction}

A review exploring the effects of participating in creative activities on health and wellbeing of children and young people found that increased self-esteem, sense of achievement, empowerment, social skills, promotion of social engagement are some of the commonly reported benefits of taking part in such activities [1]. These characteristics have been linked to resilience [2], and resilience is recognised as a component of mental wellbeing, enabling people to cope with adversity, achieve their full potential and contribute to society. Resilience is a complex construct, and within the literature a number of definitions of resilience exist. For the purposes of this paper we have adopted that of DiClemente, 
Santelli and Crosby [3] who describe it as the ability to rebound from adverse life events by positively adapting to them. Whilst the terminology varies between different authors, the core components are essentially the same. These components have been separated into intrinsic and extrinsic factors. Intrinsic factors are held within the individual or 'self' and include: the need to feel a sense of belonging and to feel secure; a sense of self efficacy, and self-esteem. Extrinsic factors on the other hand rely on others and include: having a secure attachment and relationship(s); access to wider support from family and friends; positive experiences at school and/or in the community [4].

Adolescence and early adulthood is recognised as the peak age of onset for mental ill-health which is likely to carry on into adulthood if left untreated. Research into the extent of mental ill-health amongst children and young people in the United Kingdom (UK) revealed that one in ten children and young people between the ages of five and sixteen have a diagnosable mental health condition [5]. This data is now over 10 years old, but the findings of the newly commissioned survey on children's and young people's mental health will not be published until 2018. Some predict that current prevalence of mental illhealth amongst children and young people is likely to be higher than data previously published [6]. 
Political ideology has influenced the delivery of mental health services. Prior to 2010, socio-economic factors, such as poverty and disadvantage, were accepted as being linked to mental health, and a preventative approach focussing on early intervention, with the aim of de-stigmatising mental health and inclusion was promoted. For children and young people this was translated into Child Adolescent Mental Health Services (CAMHS) designed to be accessible for all, to promote and enhance children and young people's wellbeing and mental health.

Post 2010, policy shifted and children and young people's wellbeing and mental health were no longer considered separately, instead localisation, service choice, with integration of children's and adult services was emphasised [7]. Within current policy there are a number of common threads, including the promotion of resilience and self-esteem, empowerment, and the importance of building healthy relationships $[8,9,10,11]$ The discourse now embedded in policy publications indicates increased medicalisation and individualisation of children's mental health [7]. The role of CAMHS appears to have altered and thresholds and access restrictions have been imposed, only children and young 
people who have a severe diagnosable condition are treated, with large numbers being turned away without being offered services [12]. For children and young people with mild to moderate conditions this means they may not be receiving the support they need to maintain their mental wellbeing. Indeed one in five children referred to specialist mental health services in the NHS are rejected for treatment. Furthermore, the Childrens' Commissioner's review of access to child and adolescent mental health services also revealed that young people who meet thresholds for treatment can endure long waiting lists depending on their geographical location [12].

The beginning of 2017 saw a new emphasis on mental health services with the acknowledgement once again of the costs to individuals, families, and society due to mental ill health. There was particular attention paid to the care of children and young people and the need to transform attitudes to mental health. However whilst the Prime Minister Theresa May announced a number of new initiatives there is no new funding being made available to services. There is therefore a need to explore alternatives which can be implemented to help prevent mental ill health developing, and to promote and enhance the mental wellbeing of our children and young people. 
Already, government policy supports the introduction of social prescribing schemes $[13,14]$, and arts activities are provided under social prescribing schemes around the country with evidence emerging that such schemes can produce positive outcomes for health and wellbeing [15]. Participating in creative arts has been linked to positive outcomes for children and young people such as the development of social skills and positive changes in behaviour [1]. Within the UK there are a number of organisations providing programmes of arts activities for children and young people (for example Arts and Minds (www.artsandminds.org.uk), and Start Youth Arts (www.startinsalford.org.uk). These programmes differ from art therapy interventions in the sense that they are mostly delivered by artists instead of therapists. Moreover, their aim is to promote pleasurable experiences, inclusion and social engagement rather than focussing on medicalised therapeutic outcomes.

In light of the increasing incidence of mental ill health in children and young people, and the acknowledged pressures on the statutory services, it is timely to update the review published in 2013 [1]. However, whilst the previous review 
explored the potential of creative activities to enhance the health and wellbeing of children and young people looking at broad aspects of both physical and mental health, the focus of this review is the role that participating in community-based arts plays in enhancing mental wellbeing of children and young people. To examine whether community arts interventions could provide cost-effective services that promote protective factors linked to resilience and mental wellbeing such as developing a sense of belonging and purpose, social inclusion, relationship building and improve social skills and self-esteem.

\section{Methods}

A rapid review of the literature was undertaken between June and August 2016. A rapid review can be defined as a review of the literature which has been conducted using a systematic approach within a limited time framework [16]. The database search was conducted by adopting a strategy similar to that of Daykin et al [17] however, further creative activities, such as visual arts were added to the search terminology. Following an initial scoping review where few articles using the arts to build resilience and mental wellbeing were identified, the search was widened to include other characteristics linked to mental 
wellbeing. The Boolean search keyword groupings are shown in Table 1, and searches were conducted in eighteen databases (see Table 2).

[Insert table 1 here]

[Insert table 2 here]

The search was limited to papers published in English, however no limits on the date of publication were applied. This was due to no previous reviews of similar characteristics being found during the preliminary scoping process. Publications about children and young people between the ages of 11 and 18 who participated in creative arts were included, as were publications in which the age range was extended above and/or below the search age limits. Only studies related to activities that took place within community settings and those related to extracurricular activities based within schools were included. Those within formal residential settings such as young offender institutes, residential care, special schools and hospitals were excluded. Publications based on severe mental health conditions were excluded as were studies specifically reporting on the therapies (art, music and drama). Quantitative, qualitative, and mixed-method papers were included. The inclusion and exclusion criteria are reported in Table 3.

[Insert table 3 here] 
The selected papers were independently assessed by the first and second authors [initials to be inserted here]. The articles were subject to quality assessment, however, no articles were excluded on the basis of quality. Quantitative papers were assessed using the EPPI appraisal tool [18], and qualitative studies, using the Critical Appraisal Skills Program for qualitative appraisal [19] Following Fraser and Sayah [20] a scoring system was devised to provide a rating for each study using the CASP tool. A mixed-method evaluation tool was used to appraise the mixed methods study [21]. The authors conducted independent appraisal of the selected studies and final ratings agreed following discussion.

\section{Results}

The search produced 16,882 initial hits with 132 remaining after title screening. Included in these figures are eight articles found by conducting hand searches. Abstract screening reduced this number to 72 papers and following text screening, 24 potential papers were identified. Nine duplicates were removed leaving 15 papers to be reviewed in depth by the second author. Of the 15 papers, three were rejected due to lack of recognisable methodology, three due to lack of sufficient data regarding mental health and one due to ambiguity in 
participant age range. As a result, eight papers were deemed to be of sufficient relevance to be included in the review. Of these, three used quantitative methods, four were qualitative, and one used a mixed-method approach. Four out of the seven studies were based in Australia, two were located in Canada, and two in the UK. Across the studies a range of arts activities were used drama/theatre (5), music (2), visual arts (1) and dance (3), with only one study using just one form of art activity. One of the aims of the review was to identify cost-effective interventions, but none of the included studies made any reference to costs or cost-effectiveness. It was therefore decided to conduct a further search, including the term 'cost-effectiveness' but rather than repeat the search across all the databases, a search of the databases that yielded the greatest number of 'hits' in the first search was conducted (CINAHL, Cochrane Library, PsycINFO, MEDLINE and Web of Science) but no relevant papers were found.

The literature obtained from the search was characterised in terms of study design, participant description (including sample size and age range), and country of origin, type of intervention, results and limitations of the study (see Table 4). Due to the range of research methods and outcome measurement utilised and the different arts activities included in the studies, a narrative synthesis of the findings was undertaken. 
[Insert table 4 about here]

It has been reported that most studies relating to arts, resilience and young people were mostly qualitative and based on single case studies [2]. Despite an extensive search of a broad range of databases this current review also failed to identify many studies meeting the inclusion and exclusion criteria. Only one study was found that specifically investigated changes in resilience [26]. Although none of the other studies linked the findings of their research directly to building resilience, participating in arts programmes was linked to positive youth development [27] social and emotional development [28] reduction in emotional problems [29] and the promotion of social development and wellbeing [24]. It was found that participating in arts activities does have an impact on some elements of the intrinsic and extrinsic components of resilience. The review findings are reported thematically using the conceptual framework of resilience introduced in the introduction.

Intrinsic factors

Sense of belonging \& Identity formation

Arts may play a role in identity development as the activities give people an opportunity to explore and learn about themselves. The participants in the 
Youth Arts Programme [22] linked identity with a sense of belonging, through the exposure to different people and experiences and the opportunity to meet like-minded people. Grunstein and Nutbeam developed a questionnaire to examine characteristics of resilience to investigate the extent to which resilience could be strengthened by participating in a dance/drama competition. Of the five domains of resiliency in the tool, two scales were linked to a sense of belonging and another to identity. However, the differences between pre and postintervention were not reported in the article, and a number of methodological challenges were described. In particular the difficulty in obtaining the preintervention point to commence the study, and in maintaining contact with a large cohort of students over different sites. Despite this there was an indication from the data that positive scores in a sense of belonging and for a sense of identity was negatively associated with substance misuse [26]. Another quantitative study asked participants the extent to which they felt part of a drumming group by the end of a 10 week programme. $89 \%$ strongly agreed/agreed that they felt part of the group with $92 \%$ strongly agreeing/agreeing that they enjoyed being part of the group. This was supported by feedback from teachers who observed that a sense of belonging and group cohesion were among the benefits of participation [28]. 
Confidence and self-esteem

Together increased self- confidence and self- esteem were the most commonly reported benefits of taking part in the different arts activities [22-25,28,29]. Throughout the studies both participants and observers (parents, teachers, youth workers) reported increased self- confidence and self- esteem. Increased confidence came from feeling valued, being treated like an adult, overcoming challenges, and having a purpose [22]. In addition the longitudinal study by Martin et al found that engagement in arts engagement most significantly predicted a sense of meaning/purpose in life [27]. Increased confidence was associated with both ability to perform and also in themselves, and was demonstrated in being able to communicate with others and relate to other people [24]. Wood et al using the Rosenberg self-esteem scale found a $10 \%$ increase in scores following the programme of drumming workshops.

Furthermore, in this study teachers also completed a social development evaluation form, and increased self-esteem was the most positively changed social development identified [28].

Extrinsic Factors

Secure relationships 
Team working was a common theme throughout the literature. A teacher in one study [28] noted that there was a group realisation that the whole performance relied on each individual's ability to co-operate and work as part of a team, that they all had a part in the group's success. It is interesting in this study that at the mid-point of the programme only $47 \%$ of the participants felt that the group was working well together. Unfortunately, the questions at the end-point were worded differently to the mid- point questions but at the end nearly $90 \%$ felt that the group worked well together. It was also found that $77 \%$ felt that they knew more people and how to get on with each other, and $72 \%$ were more aware about things that make relationships work. The drama-based project [24] participants felt that the activity helped to establish bonds of trust and reciprocity between the group, thus helping to form more positive relationships. For some this also extended to forming closer relationships with family members. Improved peer relationships and interpersonal skills were also reported by parents in the drama and visual arts evaluation, there was also in this study a statistically significant improvement $(p<0.01)$ in participants behaviour on the social skills development scale over the course of the programme [29]. For participants in the UK based Rock Challenge, performing and being involved in organising the performance had developed team working and created new friendships [25]. However, not only did relationships within the groups develop, 
but also the wide community was felt to be supportive too, with teachers helping through special homework arrangements and peers through audience participation.

It is also important to acknowledge that participants' experiences of taking part in such programmes is not always positive. Ennis and Tonkin reported that some participants had felt excluded by the wider group, and there were body image issues for others having to wear particular costumes for performances [22]. Moreover, some of the participants in Salmon et al's study reported disapproval and teasing from some of their peers [25].

\section{Discussion}

It is interesting to note that the majority of the projects used a variety of different arts activities (the performing arts-dance and drama, music- drumming, beat boxing, and visual arts- mask-making, and painting). Where there were a number of activities included in a programme there was no indication that participants could opt for one activity or another. The use of different activities and the opportunity to participate in a choice of activities could be a potentially important aspect to consider when developing projects. Preference for different 
activities may influence engagement and therefore impact on the individual, particularly as attendance in itself does not indicate involvement in the activity. Engagement was also discussed by Martin et al [27] who investigated whether arts engagement has a role in academic (motivation and engagement) and nonacademic (self-esteem, and life satisfaction) outcomes. Higher levels of arts engagement being found to be a predictor of having a sense of meaning and purpose, although it was noted that the quality and not the quantity of engagement was important. This was the only longitudinal survey of this type in the review, and an issue with this study was that it was reliant on self-reported activity levels. The authors acknowledged the need for further research to ascertain whether it was the arts engagement or interaction between parent and child participating in a mutual interest which could be attributed to the results. A prospective controlled study would be necessary to establish whether there is a true relationship between arts engagement and academic and non-academic outcomes. In future research the level of engagement with the activity should be also be considered, as it is not sufficient to simply count number of attendances as a proxy measure for engagement, levels of interaction and involvement with the activity is also important. 
As stated above, a range of methodologies were used in the reviewed studies. The majority of the studies reported on specific projects that had been established with the aim of investigating arts interventions in community settings on psychosocial outcomes, including: self-esteem, mental wellbeing and relationship building $[23,24,26,28,29]$. Three of these specifically developed pre/post intervention questionnaires to test effectiveness of the intervention $[26,27,29]$. These scales were tested for internal consistency using Cronbach's alpha, and two $[26,27]$ also conducted test-retest reliability measures. Despite such testing for validity and reliability suggesting a rigorous approach, it does mean that the findings cannot be used in a meta-analysis for a systematic review unless other research teams adopt similar measures in the future. Similarly, Wood et al used three different scales, including an existing validated scale [28]. However, the authors stated that the wording on some of the questions on this scale were altered to make them more 'understandable', but there was no mention of piloting or re-testing the validity of the scale. Two other questionnaires were developed for this evaluation but again there was no mention of piloting of the questionnaires or of how the questions were developed or tested, and one measure changed from the mid to end-points, with the wording of the questions being altered. 
There were also methodological issues with the qualitative studies. For example, one used a retrospective narrative approach to explore the perspectives of people who had participated in an arts programme since its inception in the 1980s [22]. Using such a method is problematic as it relies on individual recall, regardless of this the authors reported that the participants were very clear that taking part in the arts programme had contributed to selfconfidence, identity formation, and a sense of belonging. In another study focus groups and interviews were conducted but there was little detail provided as to how and when these were undertaken, or the ethical issues of conducting such research [23]. Indeed, ethical approval of the studies by a review panel was only referred to directly by three studies $[25,27,28]$, although another did state that active parental consent was gained prior to the young people participating in the research [26]. It is of concern that such reviews did not take place as these are a potentially vulnerable group and ethical review can to some extent monitor of the quality of proposed studies.

Whilst some context was provided for each of the interventions, little or no information was provided as to what happened in the arts sessions (mechanisms), or about the overall process of the programme of activities [30]. This not only makes comparison between interventions challenging but it also 
would make it difficult for others to duplicate the programmes and the research. To try and address this issue in the UK, Public Health England have recently published Arts for health and wellbeing: An evaluation framework [31]. This provides guidance on ways to document arts programmes, and its purpose is to enable meaningful comparisons to be made between interventions.

\section{Conclusion}

This review was not a full systematic review and the conclusions that can be drawn from the findings are therefore to some extent limited. However, what is clear is that there remains a significant gap in the research evidence directly linking arts participation and the promotion of mental wellbeing and resilience. There are a number of studies which have been conducted, but echoing the conclusions of other reviews in this field, many of these lack sufficient methodological rigour. Such methodological limitations reduce the potential impact of the findings, and more comprehensive systematically conducted research is required to address this. In addition, insufficient attention has been paid to the context in which the activities took place, and the mechanisms and supporting theoretical frameworks underpinning the use of the arts as 
interventions. Furthermore, few longitudinal studies have been conducted in this area making it difficult to establish the long term outcomes of these interventions. One of difficulties that the proponents of the arts for health and wellbeing face are the methodological tensions which exist due the range of academic disciplines who contribute to the research evidence, with differing perceptions as to what constitutes evidence. Healthcare commissioners mostly require evidence of effectiveness and cost benefits before they will fund interventions, and as yet there appears to be no published research that records costs of interventions or considers their cost-effectiveness. Whilst the existing evidence does provide an indication of the potential value of participating in arts activities to enhance wellbeing and resilience, further research which meets the requirements of healthcare commissioners will be necessary if the use of arts interventions are to become adjunct to traditional health service provision. Therefore there is a need to for both high quality qualitative research, and rigorously conducted controlled studies which investigate cost-effectiveness and cost benefits to be funded. In these times of fiscal restraint and with the growing concerns for the mental wellbeing of children and young people alternative interventions to reduce the incidence of mental ill health need to be considered and quickly. 


\section{Ethical Issues}

This article involved a review of existing published literature so no ethical approval was required.

\section{Conflict of Interest}

There are no potential conflicts of interest with respect to the authorship of this review and/or publication of this article.

\section{Funding}

The first author (insert initials here) was funded to undertake this review under a summer studentship scheme at [insert name of university here].

\section{References}

1. Bungay $\mathrm{H}, \&$ Vella Burrows $\mathrm{T}$. The effects of participating in creative activities on the health and wellbeing of children and young people: a rapid review of the literature Perspectives in Public Health 2013; 131:45-52 
2. Macpherson $\mathrm{H}$, Hart A and Heaver B. Building resilience through group visual arts activities: Findings from a scoping study with young people who experience mental health complexities and/or learning difficulties, 2015; Journal of Social Work, 0:1-20

3. DiClemente R, Santelli J, Crosby R. Adolescent health:

Understanding and preventing risk behaviours. Hoboken, US: JosseyBass. 2009, p 54

4. Daniel $\mathrm{B}$, \& Wassell S. Assessing and promoting resilience in vulnerable people, London: Jessica Kingsley, 2002

5. Green $\mathrm{H}$, McGinnity A, Meltzer H. et al. Mental health of children and young people in Great Britain 2004. London: Palgrave, 2005

6. Faculty of Public Health and Mental Health Foundation, Better Health for All. A Public Health Approach to mental health improvement. London: Faculty of Mental Health and Mental Health Foundation, 2016.

7. Callaghan J, Fellin L, Warner-Gale F. A critical analysis of child and adolescent mental health services policy in England. Clinical Child Psychology, Epub ahead of print 6 April 2016;

DOI:10.1177/1359104516640318 
8. Department of Health. Getting it right for children and young people: Overcoming cultural barriers in the NHS so as to meet their needs. London: Department of Health, 2010

9. Marmot M. Fair Society, Healthy Lives: Strategic Review of Health Inequalities in England post-2010. London: The Marmot Review, 2010.

10. Lewis I. Report on the Children and Young People Health Outcomes Forum. Children and Young people's Health Outcomes Strategy 2012.

11.Department of Health. Future in mind: Promoting, protecting and improving our children and young people's mental health and wellbeing. London: Department of Health, 2015.

12. Office of the Children's Commissioner for England. Lightning review: Access to child and adolescent mental health services. [online] Available at<htpps://www.childrenscommissioner.gov.uk/sites/default/files/publi cations/Children\%27s\%20Commissioner\%27s\%20Mental\%20Health \%20Lightning\%20Review.pdf 2016 [2016, Accessed 23 July 2016].

13. Department of Health. Our health our care our say, London: Department of Health, 2006. 
14.Department of Health. NHS five year forward view, London: Department of Health, 2014

15. Thomson LJ, Camic PM, Chatterjee HJ. Social Prescribing: A review of community referral schemes, London: University College London 2015

16. Pettigrew M and Roberts $\mathrm{H}$. Systematic reviews in the social sciences: A practical guide. Oxford: Blackwell Publishing, 2006

17. Daykin N, Orme J, Evans D, Salmon D, McEachran M and Brain S. The impact of participation in performing arts on adolescent health and behaviour: a systematic review of the literature. Journal of Health Psychology, 2008; 13:251-264

18. Effective Public Health Practice Project. Quality Assessment Tool for Quantitative Studies. Hamilton, Effective Public Health Practice Project, [online] Available at<http://www.ephpp.ca/index.html>[1998 Accessed 27 June 2016].

19. Critical Appraisal Skills Program (CASP). Appraisal tool for qualitative research. Oxford: Public health Resource Unit. [online] Available at<htpp:/www.phru.nhs.uk/casp/critical_appraisal_tools.htm>[2006 Accessed 16 July 2016]. 
20. Fraser KD \& Sayah F., Arts-based methods in health research: A systematic review of the literature, Arts and Health- an international journal for research policy and practice 2011; 3:110-145

21.Long AF, Godfrey M, Randall T, Brettle AJ and Grant MJ, Developing Evidence Based Social Care Policy and Practice. Part 3: Feasibility of Undertaking Systematic Reviews in Social Care. Leeds: Nuffield Institute for Health. [online] Available at<http://usir.salford.ac.uk/13070/1/Evaluative_Tool_for_Mixed_Meth od_Studies.pdf>>[2002.Accessed 27 June 2016].

22. Ennis $\mathrm{G}$ and Tonkins J. Youth arts and mental health: exploring connections in the TOP End. The Research Centre for Health and Wellbeing, Charles Darwin University 2015.

23. Hauseman DC. Youth-led community arts hubs; Self-determined learning in and out of school time (OST) program. Cogent Education, 2016; 3: 1210492

24. Kemp M. Promoting the health and wellbeing of young black men using community-based drama. Health and Education, 2006; 106:186-200

25. Salmon D, Orme J, Kimberlee R, Jones M, Murphy S. Implementing the Rock Challenge: Young people's perspectives on a drug- 
prevention and performing-arts programme Journal of Research in Nursing, 2005; 10:339-353

26. Grunstein $R$ and Nutbeam $D$. The impact of participation in the Rock Eisteddfod challenge on adolescent resiliency and health behaviours. Health Education, 2007;107:261-275

27. Martin A, Mansour M, Anderson M, Gibson R and Liem G. The role of arts participation in students' academic and non-academic outcomes: a longitudinal study of school, home, and community factors. Journal of Educational Psychology, 2013;105: 709-727

28. Wood L, Ivery P, Donovan R, Lambin E. "To the beat of a different drum": Improving the social and mental wellbeing of at-risk young people through drumming. Journal of Public Health, 2013;12:70-79

29. Wright R, Lindsay J, Alaggia R, Sheel J. Community-based arts program for youth in low income communities: A multi-method evaluation. Child and Adolescent Social Work Journal, 2006; 23:635654.

30. Pawson R and Tilley N. Realistic Evaluation. London: Sage, 1997

31. Public Health England. Arts for health and wellbeing: an evaluation framework. London: Public Health England, 2016 
Table 1. Keywords employed in the literature search

\begin{tabular}{|c|c|c|c|}
\hline $\begin{array}{l}\text { Group } 1 \\
\text { "Children and young } \\
\text { people" }\end{array}$ & $\begin{array}{l}\text { Group } 2 \\
\text { "Mental wellbeing" }\end{array}$ & $\begin{array}{l}\text { Group } 3 \\
\text { "Creative arts" }\end{array}$ & $\begin{array}{l}\text { Group } 4 \\
\text { "Effectiveness" }\end{array}$ \\
\hline $\begin{array}{l}\text { Child* } \\
\text { Adolescen* } \\
\text { Teen* } \\
\text { Youth } \\
\text { Young* } \\
\text { Juvenile* }^{*} \\
\text { Pupil }^{*} \\
\text { Student* }^{*} \\
\text { School }^{*} \\
\text { Curricul* } \\
\text { Extracurricular }\end{array}$ & $\begin{array}{l}\text { "Mental illness"” } \\
\text { "Emotional wellbeing" } \\
\text { "Mental ill-health" } \\
\text { Anxiety } \\
\text { Depression } \\
\text { Self-harm } \\
\text { Self-esteem } \\
\text { Confidence } \\
\text { Resilience } \\
\text { "Mental health" }\end{array}$ & $\begin{array}{l}\text { "Art* intervention*" } \\
\text { "Social prescribing" } \\
\text { "Participatory art"" } \\
\text { "Art* participat"" } \\
\text { "Art* activit"" } \\
\text { Music* } \\
\text { Sing* } \\
\text { Drama } \\
\text { Theat* } \\
\text { Danc* } \\
\text { "Creative activit"" } \\
\text { Song* } \\
\text { Art } \\
\text { "Visual art" } \\
\text { "Arts on prescription" } \\
+ \\
\text { Not Operating theat* }\end{array}$ & $\begin{array}{l}\text { Evaluat* }^{*} \\
\text { Research } \\
\text { Intervention* } \\
\text { Result* } \\
\text { Outcome* } \\
\text { Impact }\end{array}$ \\
\hline
\end{tabular}

\section{NOTES:}

*Truncation.

"Phrase searching"

Words within groups combined with OR 
Groups combined with AND. 
Table 2. Databases searched

\begin{tabular}{|c|c|c|c|c|c|}
\hline Database & $\begin{array}{l}\text { Initial } \\
\text { retrieval }\end{array}$ & $\begin{array}{l}\text { Results } \\
\text { after } \\
\text { Applying } \\
\text { limits }\end{array}$ & $\begin{array}{l}\text { Results after } \\
\text { title } \\
\text { screening }\end{array}$ & $\begin{array}{l}\text { Results after } \\
\text { abstract } \\
\text { screening }\end{array}$ & $\begin{array}{l}\text { Results } \\
\text { after text } \\
\text { screening }\end{array}$ \\
\hline AMED & 162 & 162 & 7 & 0 & 0 \\
\hline $\begin{array}{l}\text { British Nursing } \\
\text { Index }\end{array}$ & 459 & 459 & 21 & 15 & 4 \\
\hline CINAHL plus & 5738 & 282 & 6 & 1 & 0 \\
\hline Cochrane Library & 8071 & & 0 & 0 & 0 \\
\hline $\begin{array}{l}\text { Proquest Family } \\
\text { Health }\end{array}$ & 721 & 460 & & 0 & 0 \\
\hline $\begin{array}{l}\text { Proquest Health } \\
\text { and Medical } \\
\text { Collection }\end{array}$ & 803 & 594 & 2 & 1 & 0 \\
\hline $\begin{array}{l}\text { Proquest Public } \\
\text { Health }\end{array}$ & 2010 & 24 & 0 & 0 & 0 \\
\hline $\begin{array}{l}\text { Proquest Arts } \\
\text { and Humanities } \\
\text { full text }\end{array}$ & 1210 & 589 & 0 & 0 & 0 \\
\hline PsycINFO & 19688 & 258 & 5 & 0 & 0 \\
\hline MEDLINE & 28024 & 628 & 4 & 1 & 0 \\
\hline $\begin{array}{l}\text { British Education } \\
\text { Index }\end{array}$ & 283 & 266 & 15 & 8 & 2 \\
\hline SCOPUS & 441 & 383 & 0 & 0 & 0 \\
\hline Pubmed & 9,580 & 1058 & 7 & 0 & 0 \\
\hline Web of Science & 13,095 & 6838 & 22 & 18 & 4 \\
\hline Psyc Articles & 651 & 171 & 4 & 2 & 1 \\
\hline $\begin{array}{l}\text { Psychology and } \\
\text { behavioural } \\
\text { science } \\
\text { collection }\end{array}$ & 3855 & 3133 & 9 & 3 & 1 \\
\hline $\begin{array}{l}\text { Applied Social } \\
\text { Sciences Index } \\
\text { and abstracts } \\
\text { (ASSIA) }\end{array}$ & 1736 & 1068 & 17 & 11 & 4 \\
\hline $\begin{array}{l}\text { Child } \\
\text { Development } \\
\text { and Adolescent } \\
\text { Studies }\end{array}$ & 765 & 502 & 8 & 7 & 2 \\
\hline Hand Searches & 8 & 8 & 6 & 6 & 6 \\
\hline Total & 97,299 & 16,882 & 132 & 72 & 24 \\
\hline Duplicates & & & & & 9 \\
\hline Total selected & & & & & 15 \\
\hline $\begin{array}{l}\text { Rejected after } \\
\text { further screening } \\
\text { due to lack of } \\
\text { recognisable } \\
\text { methodology, }\end{array}$ & & & & & 8 \\
\hline
\end{tabular}




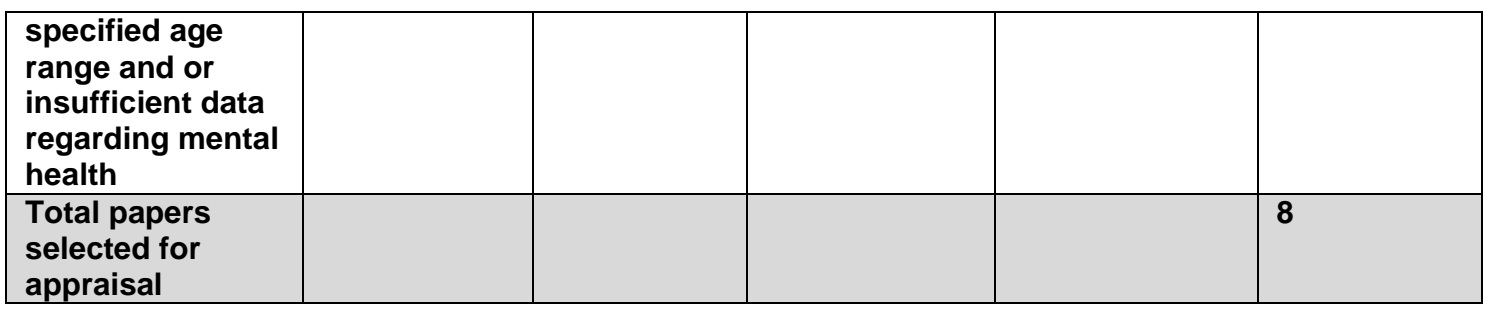


Table 3. Inclusion and exclusion criteria for selecting studies to review

\begin{tabular}{|l|l|}
\hline Inclusion Criteria & Exclusion Criteria \\
\hline $\begin{array}{l}\text { Interventions with children and young } \\
\text { people aged between } 11 \text { and } 18 \text { years } \\
\text { old. }\end{array}$ & $\begin{array}{l}\text { Children and young people under 11 or } \\
\text { over } 18 \text { years of age. } \\
\text { Community setting and school }\end{array}$ \\
(extracurricular activities) & School setting (part of the curriculum) \\
Creative arts (Sing, dance, drama, & Residential setting \\
theatre, visual arts) & Young offenders \\
English language & Children and young people in care \\
Mild to moderate mental health & Refugees \\
conditions & Children with learning difficulties \\
Abstract and full text available & Non-English language \\
Qualitative, quantitative, mixed/multi- & Severe mental health conditions \\
method studies. & No abstract or full text available \\
& No recognisable methodology available \\
& No results or outcomes or impacts \\
presented
\end{tabular}


Table 4. Characteristics of studies included in the literature review

\begin{tabular}{|c|c|c|c|c|c|c|}
\hline \multicolumn{7}{|c|}{ Qualitative } \\
\hline $\begin{array}{l}\text { Author } \\
\text { and date }\end{array}$ & Study design & $\begin{array}{l}\text { Sample } \\
\text { size, age } \\
\text { range and } \\
\text { country }\end{array}$ & Arts Activity & Key Findings & $\begin{array}{l}\text { Limitations/ } \\
\text { Comment }\end{array}$ & $\begin{array}{l}\text { CASP } \\
\text { score }\end{array}$ \\
\hline $\begin{array}{l}\text { Ennis and } \\
\text { Tonkin } \\
\text { (2015) [22] }\end{array}$ & 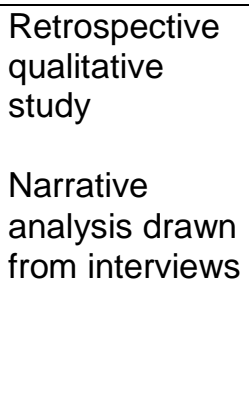 & $\begin{array}{l}17 \text { adult } \\
\text { participants } \\
\text { Age range } \\
\text { during art } \\
\text { participation } \\
(10-26) \\
\text { Darwin, } \\
\text { Australia }\end{array}$ & $\begin{array}{l}\text { Performing } \\
\text { arts (Drama } \\
\text { and circus } \\
\text { skills) }\end{array}$ & $\begin{array}{l}\text { Participants } \\
\text { reported a link } \\
\text { between arts } \\
\text { participation } \\
\text { and increased } \\
\text { confidence, } \\
\text { identity } \\
\text { formation and } \\
\text { sense of } \\
\text { belonging }\end{array}$ & $\begin{array}{l}\text { Retrospective } \\
\text { study - } \\
\text { number of } \\
\text { years since } \\
\text { participation in } \\
\text { art activity not } \\
\text { specified }\end{array}$ & $\begin{array}{c}7 \\
\text { (Moderate) }\end{array}$ \\
\hline $\begin{array}{l}\text { Hauseman } \\
(2016) \text { [23] }\end{array}$ & $\begin{array}{l}\text { Qualitative } \\
\text { case studies } \\
\text { evaluation } \\
\text { Interviews } \\
\text { Focus groups } \\
\text { Observations }\end{array}$ & $\begin{array}{l}\text { Number of } \\
\text { participants } \\
\text { in } \\
\text { programme } \\
\text { not } \\
\text { specified } \\
\text { Age range } \\
(10-18) \\
\text { Canada }\end{array}$ & $\begin{array}{l}\text { Youth-led } \\
\text { community } \\
\text { arts hubs } \\
\text { (Hip-hop } \\
\text { based arts } \\
\text { disciplines: } \\
\text { graffiti, } \\
\text { breakdancing, } \\
\text { spoken word } \\
\text { and } \\
\text { beatboxing) }\end{array}$ & $\begin{array}{l}\text { High levels of } \\
\text { engagement } \\
\text { with the } \\
\text { programme } \\
\text { Evidence of } \\
\text { increased } \\
\text { confidence } \\
\text { and } \\
\text { strengthened } \\
\text { skills in chosen } \\
\text { art form. } \\
\text { Participants } \\
\text { displayed } \\
\text { coping } \\
\text { mechanism to } \\
\text { deal with } \\
\text { stress. }\end{array}$ & $\begin{array}{l}\text { Limited detail } \\
\text { of data } \\
\text { collection and } \\
\text { analysis } \\
\text { Not clear } \\
\text { whether focus } \\
\text { of evaluation is } \\
\text { on the } \\
\text { participation in } \\
\text { the art activity } \\
\text { of the } \\
\text { programme } \\
\text { overall. }\end{array}$ & $\begin{array}{c}6 \\
\text { (Moderate) }\end{array}$ \\
\hline $\begin{array}{l}\text { Kemp } \\
(2006)[24]\end{array}$ & $\begin{array}{l}\text { Qualitative } \\
\text { Observations } \\
\text { Informal } \\
\text { conversations }\end{array}$ & $\begin{array}{l}\text { Young } \\
\text { black men } \\
\text { (Number of } \\
\text { participants } \\
\text { not } \\
\text { specified) } \\
\text { Age range }\end{array}$ & $\begin{array}{l}\text { B2B } \\
\text { Drama- based } \\
\text { health } \\
\text { promotion } \\
\text { project } \\
\text { (Story-telling, } \\
\text { theatre and } \\
\text { performance) }\end{array}$ & $\begin{array}{l}\text { Evidence of } \\
\text { increased self- } \\
\text { esteem, } \\
\text { confidence } \\
\text { self-expression } \\
\text { and self- } \\
\text { understanding, }\end{array}$ & $\begin{array}{l}\text { There is little } \\
\text { detail } \\
\text { regarding the } \\
\text { interviews. It is } \\
\text { not clear how } \\
\text { the data from } \\
\text { the creative } \\
\text { writing course }\end{array}$ & $\begin{array}{c}5 \\
\text { (Weak) }\end{array}$ \\
\hline
\end{tabular}




\begin{tabular}{|c|c|c|c|c|c|c|}
\hline & $\begin{array}{l}\text { Semi- } \\
\text { structures } \\
\text { interviews } \\
\text { Focused } \\
\text { groups } \\
\text { discussions }\end{array}$ & $\begin{array}{l}\text { (14-25) } \\
\text { South East } \\
\text { London, UK }\end{array}$ & & $\begin{array}{l}\text { and sense of } \\
\text { achievement } \\
\text { Impact on } \\
\text { social } \\
\text { relationships. } \\
\text { Reported } \\
\text { increase in } \\
\text { artistic skills } \\
\text { Increased } \\
\text { awareness of } \\
\text { stereotypes } \\
\text { and underlying } \\
\text { attitudes } \\
\text { Higher level of } \\
\text { social } \\
\text { awareness }\end{array}$ & $\begin{array}{l}\text { was collected } \\
\text { and analysed }\end{array}$ & \\
\hline $\begin{array}{l}\text { Salmon, } \\
\text { Orme, } \\
\text { Kimberlee, } \\
\text { Jones, \& } \\
\text { Murphy } \\
\text { (2005) [25] }\end{array}$ & $\begin{array}{l}\text { Qualitative } \\
\text { Focus Groups } \\
\text { and qualitative } \\
\text { data taken } \\
\text { from a survey }\end{array}$ & $\begin{array}{l}\text { Focus } \\
\text { Groups } \\
(\mathrm{n}=50 \\
\text { participants) } \\
\text { Survey }(\mathrm{n}= \\
249) . \\
\text { Age range } \\
(11-18) \\
\text { UK }\end{array}$ & $\begin{array}{l}\text { Performing } \\
\text { arts } \\
\text { competition } \\
\text { (dance and } \\
\text { drama) } \\
\text { Rock } \\
\text { Eisteddfod } \\
\text { Challenge }\end{array}$ & $\begin{array}{l}\text { Participants } \\
\text { reported: } \\
\text { increased } \\
\text { confidence, } \\
\text { peer } \\
\text { interaction, } \\
\text { sense of } \\
\text { achievement } \\
\text { (personal and } \\
\text { collective), } \\
\text { sense of } \\
\text { belonging, } \\
\text { having fun, } \\
\text { and increased } \\
\text { skill }\end{array}$ & $\begin{array}{l}\text { Focus group } \\
\text { could lead to } \\
\text { reluctance to } \\
\text { express own } \\
\text { views. Little } \\
\text { detail provided } \\
\text { as to how or } \\
\text { where focus } \\
\text { groups were } \\
\text { conducted. }\end{array}$ & $\begin{array}{c}7 \\
\text { (Moderate) }\end{array}$ \\
\hline \multicolumn{7}{|c|}{ Quantitative } \\
\hline $\begin{array}{l}\text { Author } \\
\text { and date }\end{array}$ & Study design & $\begin{array}{l}\text { Sample } \\
\text { size, age } \\
\text { range and } \\
\text { country }\end{array}$ & Arts Activity & Results & $\begin{array}{l}\text { Limitations/ } \\
\text { Comment }\end{array}$ & $\begin{array}{l}\text { EPPI } \\
\text { score }\end{array}$ \\
\hline
\end{tabular}




\begin{tabular}{|c|c|c|c|c|c|c|}
\hline $\begin{array}{l}\text { Grunstein } \\
\text { and } \\
\text { Nutbeam } \\
(2007)[26]\end{array}$ & $\begin{array}{l}\text { Quantitative } \\
\text { study using pre } \\
\text { and post } \\
\text { intervention } \\
\text { survey }\end{array}$ & $\begin{array}{l}1458 \\
\text { Students } \\
\text { Age range } \\
13-17 \\
\text { Sidney, } \\
\text { Australia }\end{array}$ & $\begin{array}{l}\text { Performing } \\
\text { arts } \\
\text { competition } \\
\text { (dance and } \\
\text { drama) } \\
\text { Rock } \\
\text { Eisteddfod } \\
\text { Challenge }\end{array}$ & $\begin{array}{l}\text { Evidence that } \\
\text { participating in } \\
\text { the program } \\
\text { could be } \\
\text { associated } \\
\text { with an } \\
\text { enhancement } \\
\text { of resiliency; } \\
\text { e.g flexibility, } \\
\text { empathy } \\
\text { sense of } \\
\text { belonging and } \\
\text { sense of } \\
\text { purpose, and } \\
\text { communication } \\
\text { skills. }\end{array}$ & $\begin{array}{l}\text { Methodological } \\
\text { problems were } \\
\text { present such } \\
\text { as difficulty in } \\
\text { identifying a } \\
\text { true pre- } \\
\text { intervention } \\
\text { point to } \\
\text { commence } \\
\text { study. } \\
\text { Difficulty in } \\
\text { identifying and } \\
\text { maintaining } \\
\text { contact with a } \\
\text { large cohort of } \\
\text { participants. }\end{array}$ & (Moderate) \\
\hline $\begin{array}{l}\text { Martin et } \\
\text { al. } \\
(2013) \text { [27] }\end{array}$ & $\begin{array}{l}\text { Quantitative } \\
\text { Longitudinal } \\
\text { Study }\end{array}$ & $\begin{array}{l}643 \\
\text { students } \\
\text { Age range } \\
(10-18) \\
\text { Australia }\end{array}$ & $\begin{array}{l}\text { Students were } \\
\text { asked to } \\
\text { report on } \\
\text { levels of } \\
\text { Art } \\
\text { participation } \\
\text { (School-based } \\
\text { extracurricular, } \\
\text { home-based } \\
\text { and } \\
\text { community- } \\
\text { based) } \\
\text { (Art, drama, } \\
\text { film/ } \\
\text { media and } \\
\text { music) }\end{array}$ & $\begin{array}{l}\text { Identified } \\
\text { school, home } \\
\text { and } \\
\text { community- } \\
\text { based arts } \\
\text { participation } \\
\text { factors linked } \\
\text { to the } \\
\text { prediction of } \\
\text { academic and } \\
\text { non-academic } \\
\text { outcomes } \\
\text { (self-esteem, } \\
\text { meaning and } \\
\text { purpose, life } \\
\text { satisfaction). }\end{array}$ & $\begin{array}{l}\text { Only self- } \\
\text { reported data } \\
\text { available } \\
\text { Questionable } \\
\text { as to whether } \\
\text { the positive } \\
\text { results can be } \\
\text { attributed to } \\
\text { arts } \\
\text { participation or } \\
\text { to any other } \\
\text { activity } \\
\text { participation }\end{array}$ & (Weak) \\
\hline
\end{tabular}




\begin{tabular}{|c|c|c|c|c|c|c|}
\hline $\begin{array}{l}\text { Wood, } \\
\text { Ivery, } \\
\text { Donovan } \\
\text { and } \\
\text { Lambin } \\
\text { (2013) [28] }\end{array}$ & $\begin{array}{l}\text { Quantitative } \\
\text { pre, interim } \\
\text { and post } \\
\text { intervention } \\
\text { questionnaires }\end{array}$ & $\begin{array}{l}180 \\
\text { students } \\
\text { Age range } \\
\text { Not } \\
\text { specified } \\
\text { but included } \\
\text { primary and } \\
\text { secondary } \\
\text { school } \\
\text { children } \\
\text { At-risk } \\
\text { youth } \\
\text { Australia }\end{array}$ & $\begin{array}{l}\text { 'Drum Circle' } \\
\text { Group } \\
\text { hand } \\
\text { drumming } \\
\text { Ten week } \\
\text { program } \\
\text { School-based }\end{array}$ & $\begin{array}{l}10 \% \text { increase } \\
\text { in self-esteem } \\
\text { scores on the } \\
\text { adapted } \\
\text { Rosenberg } \\
\text { self-esteem } \\
\text { scale } \\
29 \% \text { decrease } \\
\text { in reported } \\
\text { behavioural } \\
\text { incidents } \\
\text { Reported } \\
\text { observed } \\
\text { benefits such } \\
\text { as group } \\
\text { cohesion, } \\
\text { more positive } \\
\text { interaction with } \\
\text { others, } \\
\text { improved } \\
\text { willingness to } \\
\text { learn and } \\
\text { follow } \\
\text { instructions }\end{array}$ & $\begin{array}{l}\text { Budget and } \\
\text { logistic } \\
\text { constrains and } \\
\text { school } \\
\text { timetabling did } \\
\text { not allow for } \\
\text { the use of a } \\
\text { control group. } \\
\text { This weakened } \\
\text { the rigor of the } \\
\text { evaluation. } \\
\text { Scale items on } \\
\text { one of the } \\
\text { questionnaires } \\
\text { changed } \\
\text { between } \\
\text { interim and } \\
\text { post } \\
\text { intervention }\end{array}$ & (Weak) \\
\hline & & & \multicolumn{4}{|l|}{$\begin{array}{l}\text { Mixed } \\
\text { methods }\end{array}$} \\
\hline $\begin{array}{l}\text { Author } \\
\text { and date }\end{array}$ & Study design & $\begin{array}{l}\text { Sample } \\
\text { size, age } \\
\text { range and } \\
\text { country }\end{array}$ & Arts Activity & Results & $\begin{array}{l}\text { Limitations/ } \\
\text { Comment }\end{array}$ & Score \\
\hline $\begin{array}{l}\text { Wright, } \\
\text { Lindsay, } \\
\text { Alaggia } \\
\text { and Sheel } \\
\text { (2006) [29] }\end{array}$ & $\begin{array}{l}\text { Multi method } \\
\text { evaluation } \\
\text { Qualitative } \\
\text { interviews } \\
\text { Quantitative } \\
\text { methods: } \\
\text { Observations, } \\
\text { attendance } \\
\text { forms, } \\
\text { standardised } \\
\text { behaviour } \\
\text { checklists and }\end{array}$ & $\begin{array}{l}183 \text { young } \\
\text { people } \\
\text { Low income } \\
\text { Age range } \\
9-15 \\
\text { Canada }\end{array}$ & $\begin{array}{l}9 \text { month } \\
\text { program } \\
\text { (total of } 74 \\
\text { sessions) } \\
90 \text { minute art } \\
\text { sessions- } \\
\text { twice weekly } \\
\\
\text { Theatre and } \\
\text { visual arts } \\
\text { (mask-making, } \\
\text { design and } \\
\text { painting) }\end{array}$ & $\begin{array}{l}\text { Reported } \\
\text { increased self- } \\
\text { esteem, and } \\
\text { confidence. } \\
\text { Improved } \\
\text { interpersonal } \\
\text { skills, peer } \\
\text { interaction, } \\
\text { conflict } \\
\text { resolution, and } \\
\text { problem } \\
\text { solving skills. }\end{array}$ & $\begin{array}{l}\text { Risk of } \\
\text { potential bias } \\
\text { in the research } \\
\text { assistants' } \\
\text { observations. } \\
\text { The group's } \\
\text { acceptance to } \\
\text { participate } \\
\text { could be } \\
\text { associated } \\
\text { with their } \\
\text { motivation to } \\
\text { change which }\end{array}$ & (Weak) \\
\hline
\end{tabular}




\begin{tabular}{|l|l|l|l|l|l|l|}
\hline $\begin{array}{l}\text { pre, interim } \\
\text { and post } \\
\text { intervention } \\
\text { questionnaires. }\end{array}$ & & $\begin{array}{l}\text { Enhanced art } \\
\text { Based in low } \\
\text { income } \\
\text { Communities }\end{array}$ & $\begin{array}{l}\text { could lead to } \\
\text { skills }\end{array}$ & $\begin{array}{l}\text { Significant } \\
\text { pocrease in } \\
\text { emotional bias. } \\
\text { problems } \\
\text { (unhappiness, } \\
\text { anxiety and } \\
\text { depression) }\end{array}$ & & \\
& & & & \\
& & & & \\
& & & & & \\
& & & & \\
\hline
\end{tabular}

